\title{
Funaria hygrometrica moss as Bio-indicator of Atmospheric Pollution of Polycyclic Aromatic Hydrocarbons (PAHs) in Makurdi-Nigeria: Occurrence and Sources
}

\author{
Peter Agorye Adie ${ }^{*}$, Akosu Andrew Kor, Ahola David Oklo and Chris Oche Ikese \\ Department of Chemistry, Benue State University, PMB 102119, Makurdi, Nigeria \\ Corresponding Author* \\ DOI: https://dx.doi.org/10.51244/IJRSI.2021.8402
}

\begin{abstract}
The sixteen (16) polycyclic aromatic hydrocarbons (PAHs), compounds listed by the US EPA for priority attention were quantitated in moss samples in the study area to ascertain atmospheric pollution levels of these compounds. PAHs compounds in the digested samples were identified and quantitated by the gas chromatographic-mass spectrometric (GC-MS) technique using column injector in splitless mode. In many of the samples the machine returned Nd, revealing low levels of PAHs contamination in the area. Concentrations of PAHs in the samples ranged from, not detected (Nd) to $7.89 \mathrm{ng} / \mathrm{g}$. Naphthalene, a two-ring PAH showed the most dominance, occurring in 12 of the 15 samples, while benzo[a,h]anthracene, indeno $[1,2,3-c d]$ pyrene and benzo[ghi]perylene were not detected in any of the samples. Ankpa and Gaadi recorded $0.00 \mathrm{ng} / \mathrm{g}$ total PAHs concentration/site, while sample from Modern Market showed highest total PAHs concentration of $11.54 \mathrm{ng} / \mathrm{g}$. Application of molecular ratios in source identification revealed that the PAHs fluxes in the samples derived from both pyrogenic and petrogenic origins.
\end{abstract}

Keywords: Polycyclic aromatic hydrocarbons, Funaria hygrometrica moss, bio-indicator, atmospheric pollution, Makurdi

\section{INTRODUCTION}

$\mathrm{M}$ osses are small flowerless plants that typically grow in dense green clumps or mats, often in damp or shady locations (Buck and Goffinet, 2000). The individual plants are usually composed of simple leaves that are generally only one cell thick, attached to a stem that may be branched or unbranched and play only a limited role in conducting water and nutrients (Buck and Goffinet, 2000; Goffinet and Buck, 2004). Although some species have conducting tissues, these are generally poorly developed and structurally different from similar tissue found in vascular plants. Mosses do not have seeds and after fertilisation develop sporophytes with unbranched stalks topped with single capsules containing spores (Fu et al., 2012; Kang et al. 2016). They are nonvascular, herbaceous, non-woody plants that absorb water and nutrients mainly through their leaves and harvest carbon dioxide and sunlight to create food by photosynthesis. As sentinel organisms, moss plants are commonly used as bio- indicators of air pollutants because they are readily available and can integrate air pollutants over a long period of time, making them well suited for measuring chronic low-levels of air pollution (Buck and Goffinet 2000; Lim et al., 2006).

Polycyclic aromatic hydrocarbons (PAHs) are a class of hazardous organic compounds consisting of three or more benzene rings fused in various structural configurations with no heteroatoms or substituents. They are subset of organic compounds known as persistent organic pollutants, POPs (Adie et al., 2014; Abdel-Shafy, 2016). In PAHs, carbon and hydrogen atoms are bonded in simple to complex ring systems in the benzene ring arrangements, conferring a wide diversity of physical, and chemical characteristics. As a member of POPs, they possess the family characteristics of persistence in the environment, bioaccumulation in animal and human tissues, potential toxicity and long-range transport, hence, their presence in areas far removed from point of discharge. They are mostly colourless, white, or pale yellow solids. PAHs in the environment are derived principally from natural and technogenic sources (Srogi, 2007; Ravindra et al., 2008; Ramesh et al., 2011; Abdel-Shafy and Mansour, 2016). The major source of PAHs is the incomplete combustion of carbon bearing materials such as coal, fossil fuels, garbage and wood. Source apportionment studies classify PAHs in the environment as derived from biogenic, petrogenic and pyrogenic processes. Biogenic PAHs are those produced biologically by certain plants and bacteria during the degradation of vegetative materials; and by other natural processes such as forest fires, volcanic activities, bacterial and algal synthesis, seepages from oil deposits and sedimentary rocks abrasion (Ma et al., 2013; Liu et al., 2016). Biogenic PAHs such as cadelene, simonellite and retene derived from higher plants by diagenetic processes have been reported $(\mathrm{Ma}$ et al., 2013; Oyo-Ita et al.,2013; Adie et al., 2014). Petrogenic PAHs derive from crude oil exploration activities including exploitation, transportation, storage and usage. Pyrogenic PAHs are those formed whenever carbon bearing substances are burned at high temperatures (Offiong et al.,2012; Wang et al., 2012; Abdel-Shafy and Mansour, 2016; Liu et al., 2016). 
Many useful products such as mothballs, blacktop and creosote contain PAHs. They are also found at low concentrations in skin creams and anti-dandruff shampoos that contain coal tars. Although largely insoluble in water, low molecular congeners are soluble and dissolve in water and enter groundwater from ash, tar or creosote improperly disposed in landfills. In aquatic organisms PAHs may enter through respiratory organs by ingestion or through the skin (Liu et al., 2013; Ma et al., 2013). In humans, PAHs exposure may occur through breathing, drinking, eating or touching. This group of approximately 10,000 organic compounds has received global attention due to their toxic, mutagenic and carcinogenic properties (Chen et al., 2007; da Silva et al., 2007; Li et al., 2010).

Incineration is often the option adopted by residents of Makurdi and indeed, many parts of Nigeria to reduce, and or, eliminate solid wastes, and by farmers in the suburbs to prepare farmlands for cultivation. This practice has the potential of releasing PAHs into the atmosphere. There is therefore the need to conduct atmospheric auditing of the area from time to time to ascertain its purity, or otherwise. This research was therefore designed to investigate the occurrence and sources of polycyclic aromatic hydrocarbons in the atmosphere in Makurdi and environs using Funaria hygrometrica moss as bio-indicator.

\subsection{The Study area}

Makurdi is the administrative headquarters of Benue State in the middle belt area of Nigeria. It lies within latitudes $7.73^{\circ} \mathrm{N}$ and $7.44^{\circ} \mathrm{N}$, and longitudes $8.52^{\circ} \mathrm{E}$ and $8.32^{\circ} \mathrm{E}$. It is situated on an elevation of 104 metres above sea level with a population of 297,398 and sits on an area of approximately $804.35 \mathrm{~km}^{2}$. The soils are derived from Precambrian basement complex rocks and quaternary alluvial deposits of the Benue River as parent materials (Adie et al., 2014). The annual rainfall ranges between 1,200 to $1650 \mathrm{~mm}$ and is distributed between March/April and October/November preceding a marked season of dryness lasting usually four months. This sprawling town is bisected by the River Benue, from where the State derives its name into, North Bank and South Bank. The town has the Tiv speaking tribe as its traditional inhabitants, who are predominantly agrarian, cultivating cash crops ranging from yams, cassava, potato as well as fruits of various kinds, all at subsistence levels. Makurdi is home to every tribe in Nigeria given its history as a railway stopover station. In recent times the city has attracted an influx of internally displaced persons as a result of various crises rocking the country. This has increased the population of artisans of various skills and persuasions. The resultant effect is a spike in environmental pollutants in the area. Being a nodal town, Makurdi plays host to a huge volume of vehicular movements crisscrossing the length and breadth of the country.

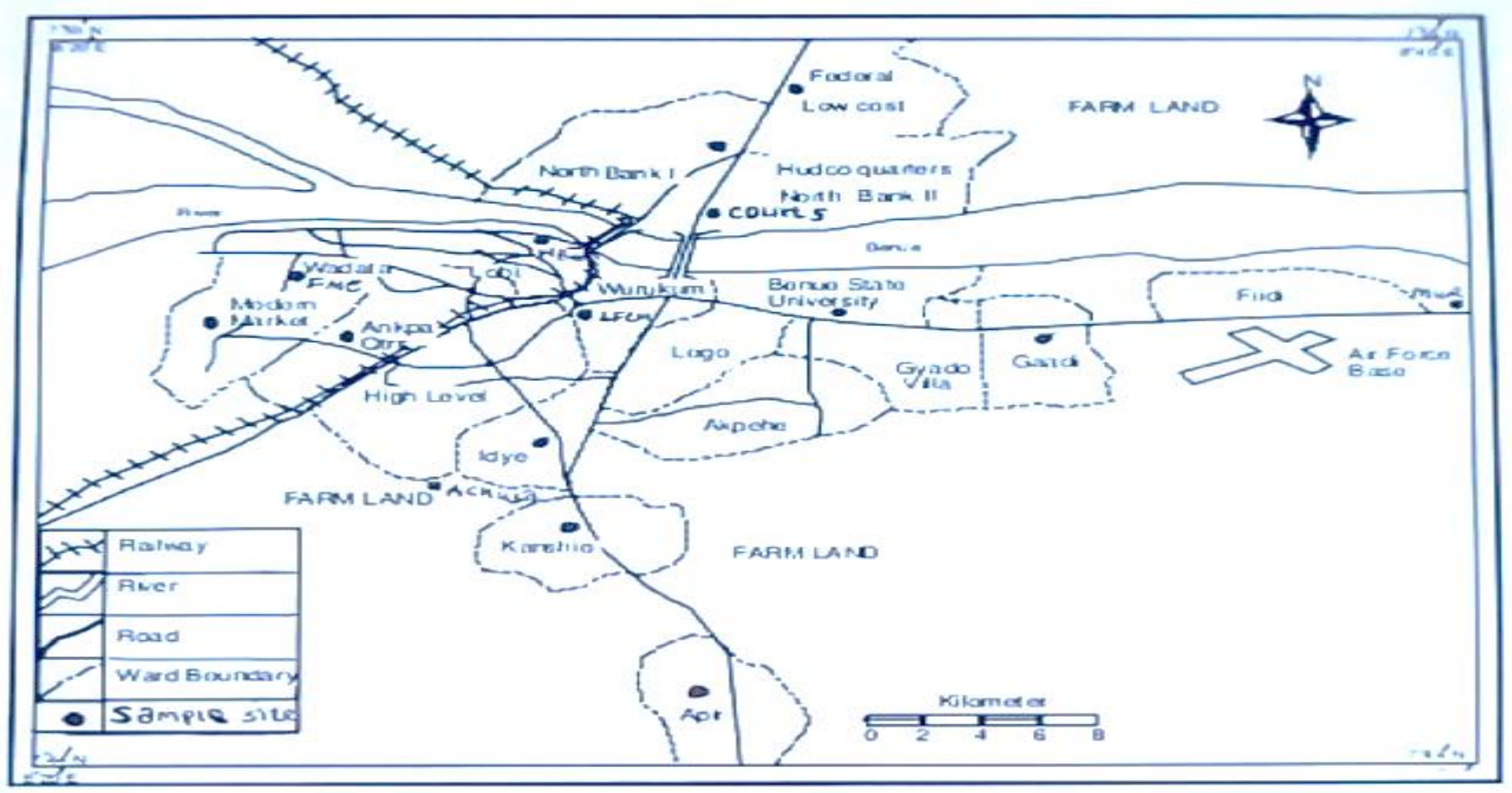

\section{MATERIALS AND METHODS}

\subsection{Sample collection and preparation}

Funaria hygrometrica samples were collected from 15 different locations to reflect a good spatial coverage of
Makurdi town and its environs between the months of May and August 2019. The sampling sites were selected in a manner that best represents the local deposition pattern with respect to topography and dominant wind directions. Factors such as temperature, humidity, rainfall and sunshine that 
favour the growth of moss plants were consideration. Each sampling site typically consisted of colonies of the moss species. The sampling locations were at the following areas; Achusa Village, Ankpa Quarters, Apir Village, Court 5, Federal Low Cost (FLC), Federal Medical Center (FMC), Gaadi Comprehensive College, Idye Village, Kanshio Village, Wurukum, Modern Market, Mu River bridge, Water Board Makurdi, Benue State University and North Bank.

With the aid of sterilized spatula, samples were collected by scraping them from the substrates into the steel tray and were immediately transferred into aluminum foil (Lane, 1989). Each sample was collected from different habitats ranging from blocks to walls of buildings, bark of large trees and culverts. The samples were wrapped in an aluminum foil to protect them from light and kept in icebox and transported to the laboratory for analysis.

Samples were carefully cleaned of adhering impurities under dry conditions. Only the green leafy parts of the moss known as the gametophytes were used for analysis.

\subsection{Sample extraction}

The glassware used in this work were thoroughly washed with water and detergent, and rinsed with excess distilled water. They were allowed to drain and thereafter placed in the electric oven at $105{ }^{\circ} \mathrm{C}$ for 6 hours in order to get rid of any traces of organic compounds. The ground sample $(1.0 \mathrm{~g})$ was mixed with anhydrous sodium sulphate $(1: 1 \mathrm{w} / \mathrm{w})$, in order to remove traces of moisture from the sample and then sonicated with $3 \times 40 \mathrm{~mL}$ of dichloromethane (DCM), for four hours, and the extracts bulked. The bulked extract was reduced to 1.0 $\mathrm{mL}$ using vacuum rotary evaporator (Laborota 4001, LabPlant, Huddersfield, England) prior to clean up.

\subsection{Sample clean-up}

The sample was subjected to column chromatographic separation using silica gel (United States Environmental Protection Agency Standard Silica Gel Clean Up Methods). The thoroughly washed, rinsed and packed column was preeluted with $20 \mathrm{~mL}$ hexane. The acid silica gel was prepared by mixing high purity (> 95\%, Merck) concentrated tetraoxosulphate (VI) acid with silica gel in the ratio 1: 8 by volume. The sample was then eluted with $100 \mathrm{~mL}$ hexane followed by $200 \mathrm{~mL}$ of dichloromethane. The eluate was reduced under pressure to approximately $1 \mathrm{~mL}$ prior to injection into the GC-MS.

\subsection{PAHs analysis}

Using column injector, the sample was injected in splitless mode at the injection temperature of $300^{\circ} \mathrm{C}$ into the GC-MS with an injection time of 1 minute for detection and identification of PAHs in the matrix. An isocratic mobilephase mixture of 37.5: 62.5 (v/v) acetonitrile and water containing tetramethyl ammonium perchlorate and $0.1 \mathrm{~mL}$ of $70 \%$ (vlv) $\mathrm{HClO}_{4}$ were used to elute the sample through guard and $7.5 \mathrm{~mm}$ analytical column. The remaining constituents, including the analyte were removed by washing the cartridge with $0.25 \mathrm{~mL}(\mathrm{vlv})$ mixture of $0.1 \mathrm{M} \mathrm{HClO}_{4}$ and acetonitrile with a purified helium used as carrier gas with a flow rate of $1.5 \mathrm{~mL} / \mathrm{min}$. A $50 \mathrm{~mL}$ aliquot was injected unto $15 \mathrm{~cm} \times 4.6 \mathrm{~mm}$ column coated with $10 \mu \mathrm{m}$ porous silica with $\mathrm{C}_{8}$-bonded stationary phase with an injection time of 1 min. The individual identification of the compounds was based on their retention time in comparison with those of the standards and on the ratio mass to charge $(\mathrm{m} / \mathrm{z})$ of the quantitation ion of each compound.

The peak of each analyte in the sample chromatogram was identified by comparing its relative retention time (RRT) with the RRT of the analyte in the chromatogram of the standard mixture. The quantitative calculation for each compound was done by comparing its relative peak area (RPA) in the sample chromatogram with its (RPA) in the chromatogram of the standard mixture using one-point calibration method. The concentrations in moss plant tissue is a reflection of its total atmospheric concentration in a given location.

\subsection{Analytical method validation}

The analytical procedure was optimized for identification and quantitation of PAHs using analytical protocols adopted by the International Conference on Harmonization, ICH, of the European Medicines Agency (EMEA, 2006). Recovery studies, linearity, precision, accuracy limits of detection and limits of quantitation were optimized.

Recovery of the 16 PAHs relied on the use of surrogates as internal standard. The average recovery of the internal standard ranged from between $66.31 \%$ and $92.48 \%$, while the relative standard deviation (RSD) was between $1.07 \%$ and $7.81 \%$. The data falls within the acceptable values of the United States Environmental Protection Agency, USEPA (2010), criteria. The detection limits, DL, of the instrument was obtained from the equation; $D L=3 \sigma / \mathrm{s}$, while the quantitation limits $\mathrm{QL}$, was calculated from $Q L=10 \sigma / \mathrm{s}$, where $\sigma$, is the standard deviation of the analyte's blank and s, the slope of the calibration curve.

Method linearity for compound identification was evaluated by plot of response against retention time, while compound quantitation was obtained from the plot of peak area against compound concentration of working calibration standards. Precision utilized repeatability of six determinations, and relied on the relative standard deviation, RSD, of the run data. The accuracy of the method was evaluated by comparing data with results of reference standards.

\section{RESULTS AND DISCUSSION}

The study set out to identify and quantitate sixteen (16) US EPA priority PAHs in moss samples harvested within and around Makurdi, the Benue State capital in the middle belt region of Nigeria. Results of the GC-MS analysis is presented in Table 1. Data revealed that moss samples obtained from Ankpa quarters and Gaadi Comprehensive Secondary School area completely lacked any of the PAHs investigated. Naphthalene, a 2 ring PAH was the most prevalent in the 
samples, occurring in all but samples from Ankpa quarters and Gaadi area. Moss samples from Modern market and Wurukum indicated highest frequencies of PAHs occurrence. These are areas of dense economic and commercial activities, and housing the biggest markets in Makurdi metropolis. Samples from Benue State Water Board area, Benue State University and North Bank axis of the town were the next to indicate high PAHs frequencies of occurrence with values of 8, 6, 6 respectively. Samples from Apir, an area that hosts auto mechanic village has PAHs occurrence frequency of 5 , while the remaining samples indicated frequencies of 1 or 2.

Total PAHs concentration per site ranged from 0.00 to 11.54 $\mathrm{ng} / \mathrm{g}$. Moss samples from modern market indicated highest total PAHs concentration of $11.54 \mathrm{ng} / \mathrm{g}$. Results indicated samples from residential areas of Achusa, Ankpa, and Gaadi recorded $0.00 \mathrm{ng} / \mathrm{g}$ of total PAHs concentrations, whereas, areas of high economic and commercial activities showed concentrations proportional to anthropogenic activities.

A quick glance at the results in Table 1 would impress a benign PAHs profile in the samples studied because many samples turned out, not detected (ND) response. However, a closer look at some of the results at Wurukum, Modern Market and Benue State Water Board showed concentrations that exceeded threshold limits value, TLV set by regulatory authorities. For instance, naphthalene WKM (2.02 ng/g), MMK (7.83 ng/g), WBM (1.09 ng/g); fluorene MMK (1.04 $\mathrm{ng} / \mathrm{g})$; anthracene MMK (0.89 ng/g); phenanthrene MMK (1.05 ng/g); benzo[a]anthracene MMK (0.11 ng/g); chrysene WKM (0.08 ng/g), MMK (0.08 ng/g); benzo[b]fluoranthene $(0.07 \mathrm{ng} / \mathrm{g})$ and benzo[e]pyrene WKM (0.01 ng/g), MMK $(0.06 \mathrm{ng} / \mathrm{g}), \mathrm{WBM}(0.01 \mathrm{ng} / \mathrm{g})$ all showed concentrations that exceeded threshold levels.

Among the PAHs detected, lower molecular weight (LMW) compounds were the prevalent, whereas, the higher molecular weight (HMW) congeners were sparsely found, implying that PAHs load in the study area derive mostly from petrogenic sources. Sowles (2005) reported that HMW PAHs are less acutely toxic but more carcinogenic than LMW PAHs. In general, HMW PAHs degrade less rapidly and therefore accumulate more in the environment. It must be stated here that PAHs source identification relying only on molecular weight is insufficient and other indices are often employed to support this.

\subsection{PAHs Source apportionment by molecular ratios}

Table 2 gives molecular ratios of the PAHs detected and quantified in the studied samples, while a 2-tailed Pearson correlation statistics of the molecular ratios is presented in Table 3. Molecular ratio makes use of relative concentrations of PAHs isomers detected and quantified in the environment to evaluate the sources of the compounds. For instance, phenanthrene and anthracene, both with a molecular weight of 178 are known to have different thermodynamic and kinetic stabilities in the environment. A ratio of $\mathrm{Ph} / \mathrm{A}>1$, is indicative of petroleum inputs, because phenanthrene is found in high concentration in petroleum. Table 2 therefore indicates that PAHs in the study area derive from both petrogenic and pyrogenic fluxes. FlA/(FlA + Py) from Table 2 also suggest mixed sources of the compounds. Yunker et al. (2002) suggested that petroleum combustion products have a $\mathrm{FlA} /(\mathrm{FlA}+\mathrm{Py})$ range of between 0.4-0.5, while PAHs from combustion stubble and other vegetation materials have ratios greater than 0.5 . The ratio $\mathrm{A} /(\mathrm{A}+\mathrm{Ph})$ have equally been used in apportioning sources to PAHs in some studies. Yan et al. (2006) reported that values $<0.1$ indicate petrogenic sources, while values $>0.1$ implies combustion sources. Results in Table 2 therefore ascribe pyrogenic contributions to PAHs in the study areas. The anthracene-phenanthrene ratio show strong correlation which is significant at the 0.01 level (2tailed). Yunker et al. (2003) indicated that $\mathrm{BaA} /(\mathrm{BaA}+\mathrm{Chy})$ values $<0.2$ implies petrogenic inputs, while values $>0.35$ are combustion derived. Table 2 therefore indicates that $\mathrm{BaA}$ and Chy identified in MMK were solely from pyrogenic activities. $\mathrm{BaA}$ and Chy ratio correlated with FlA and Py which is significant at the 0.05 level (2-tailed), Table 3.

\section{CONCLUSION}

Thirteen (13) of the sixteen (16) USA EPA listed PAHs were detected and quantitated in the moss samples. None of the PAHs studied was detected in samples from Ankpa and Gaadi. High molecular weight benzo[ah]anthracene, indeno[1,2,3]pyrene and benzo[ghi]perylene were those not detected at all in any of the samples. Most of the samples returned, not detected (nd) for majority of the compounds, suggesting low pollution levels of the compounds in the area under study. Although occurrence of PAHs in the study area was not extensive, there are some worrying signs as some of the detected and quantified compounds such as anthracene and phenanthrene (MMK) showed concentrations which exceeded the threshold values.

Molecular ratios used in source identification revealed mixed sourcing of PAHs from combustion and petroleum-related activities. Statistical treatment of the data using Pearson correlation matrix confirmed mixed sourcing of PAHs in the moss samples studied. 
International Journal of Research and Scientific Innovation (IJRSI) | Volume VIII, Issue IV, April 2021 | ISSN 2321-2705

Table 1: Concentration of PAHs (ng/g) in moss samples in the study area

\begin{tabular}{|c|c|c|c|c|c|c|c|c|c|c|c|c|c|c|c|c|}
\hline $\begin{array}{l}\text { Compound Number } \\
\text { of rings }\end{array}$ & U & 学 & 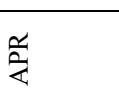 & $\hat{\vartheta}$ & 岂 & $\sum_{i}^{0}$ & 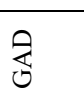 & $\stackrel{\text { Ir }}{=}$ & $\begin{array}{l}\stackrel{0}{0} \\
y\end{array}$ & $\sum$ & $\sum_{\Sigma}^{u}$ & 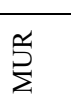 & $\sum_{j}^{m}$ & $\vec{\infty}_{\infty}$ & $\sum_{\bar{z}}$ & 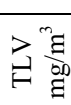 \\
\hline $\begin{array}{c}\text { Naphthalene } \\
2\end{array}$ & ND & ND & $\begin{array}{l}0.15 \pm 0.0 \\
01\end{array}$ & $\begin{array}{c}0.13 \\
\pm 0.0 \\
01\end{array}$ & $\begin{array}{c}0.08 \\
\pm 0.0 \\
00\end{array}$ & $\begin{array}{c}0.09 \\
\pm 0.0 \\
00\end{array}$ & ND & $\begin{array}{l}0.1 \\
0 \pm \\
0.0 \\
01\end{array}$ & $\begin{array}{c}0.16 \pm 0 . \\
002\end{array}$ & $\begin{array}{c}2.02 \pm 0 \\
003\end{array}$ & $\begin{array}{l}7.83 \pm \\
0.003\end{array}$ & $\begin{array}{c}0.06 \\
\pm 0.0 \\
00\end{array}$ & $\begin{array}{l}1.09 \pm \\
0.002\end{array}$ & $\begin{array}{l}0.18 \pm \\
0.001\end{array}$ & $\begin{array}{l}0.11 \pm \\
0.001\end{array}$ & 0.2 \\
\hline $\begin{array}{c}\text { Acenaphthylene } \\
3\end{array}$ & ND & ND & ND & ND & ND & ND & ND & ND & ND & $\begin{array}{c}0.05 \pm 0 . \\
000\end{array}$ & $\begin{array}{l}0.12 \pm \\
0.001\end{array}$ & $\mathrm{ND}$ & $\begin{array}{l}0.02 \pm \\
0.000\end{array}$ & $\begin{array}{l}0.01 \pm \\
0.000\end{array}$ & ND & 0.2 \\
\hline $\begin{array}{c}\text { Acenaphthene } \\
3\end{array}$ & $\mathrm{ND}$ & ND & ND & ND & ND & ND & ND & ND & ND & $\begin{array}{c}0.04 \pm 0 . \\
000\end{array}$ & $\begin{array}{l}0.17 \pm \\
0.001\end{array}$ & $\mathrm{ND}$ & $\begin{array}{l}0.01 \pm \\
0.000\end{array}$ & $\begin{array}{l}0.01 \pm \\
0.000\end{array}$ & ND & 0.2 \\
\hline $\begin{array}{c}\text { Fluorene } \\
3 \\
\end{array}$ & $\mathrm{ND}$ & $\mathrm{ND}$ & ND & ND & $\mathrm{ND}$ & 0.02 & ND & $\begin{array}{c}0.0 \\
4\end{array}$ & ND & $\begin{array}{c}0.09 \pm 0 . \\
001\end{array}$ & $\begin{array}{l}1.04 \pm \\
0.003 \\
\end{array}$ & ND & $\begin{array}{l}0.09 \pm \\
0.000\end{array}$ & $\begin{array}{l}0.01 \pm \\
0.000\end{array}$ & 0.06 & 0.2 \\
\hline $\begin{array}{c}\text { Anthracene } \\
3 \\
\end{array}$ & ND & ND & $\begin{array}{c}0.02 \pm 0.0 \\
00 \\
\end{array}$ & ND & ND & ND & ND & ND & ND & $\begin{array}{c}0.02 \pm 0 . \\
000\end{array}$ & $\begin{array}{l}0.89 \pm \\
0.002 \\
\end{array}$ & ND & $\begin{array}{l}0.01 \pm \\
0.000\end{array}$ & $\begin{array}{l}0.03 \pm \\
0.000 \\
\end{array}$ & 0.07 & 0.2 \\
\hline $\begin{array}{c}\text { Phenanthrene } \\
3\end{array}$ & ND & $\mathrm{ND}$ & $\begin{array}{c}0.03 \pm 0.0 \\
00\end{array}$ & ND & ND & ND & ND & $\mathrm{ND}$ & ND & $\begin{array}{c}0.11 \pm 0 . \\
002\end{array}$ & $\begin{array}{l}1.05 \pm \\
0.003\end{array}$ & ND & $\begin{array}{l}0.06 \pm \\
0.000\end{array}$ & $\begin{array}{l}0.01 \pm \\
0.000\end{array}$ & 0.04 & 0.2 \\
\hline $\begin{array}{c}\text { Fluoranthene } \\
4\end{array}$ & $\mathrm{ND}$ & $\mathrm{ND}$ & ND & ND & ND & ND & ND & $\mathrm{ND}$ & ND & $\begin{array}{c}0.02 \pm 0 . \\
000\end{array}$ & $\begin{array}{l}0.09 \pm \\
0.001\end{array}$ & $\mathrm{ND}$ & ND & ND & ND & 0.2 \\
\hline $\begin{array}{c}\text { Pyrene } \\
4\end{array}$ & $\mathrm{ND}$ & $\mathrm{ND}$ & $\begin{array}{c}0.07 \pm 0.0 \\
01\end{array}$ & ND & ND & ND & ND & $\mathrm{ND}$ & ND & $\begin{array}{c}0.03 \pm 0 . \\
000\end{array}$ & $\begin{array}{l}0.03 \pm \\
0.000\end{array}$ & $\mathrm{ND}$ & $\begin{array}{l}0.01 \pm \\
0.000\end{array}$ & ND & ND & 0.2 \\
\hline $\begin{array}{c}\text { Benzo }[a] \text { anthracene } \\
4\end{array}$ & ND & ND & ND & ND & ND & ND & ND & ND & ND & ND & $\begin{array}{l}0.11 \pm \\
0.002\end{array}$ & ND & ND & ND & ND & $\begin{array}{c}0.00 \\
02\end{array}$ \\
\hline $\begin{array}{l}\text { Chrysene } \\
4\end{array}$ & ND & ND & $\begin{array}{c}0.01 \pm 0.0 \\
00\end{array}$ & ND & ND & ND & ND & ND & ND & $\begin{array}{c}0.05 \pm 0 . \\
000\end{array}$ & $\begin{array}{l}0.08 \pm \\
0.000\end{array}$ & ND & ND & ND & $\begin{array}{l}0.01 \pm \\
0.000\end{array}$ & $\begin{array}{c}0.00 \\
02\end{array}$ \\
\hline $\begin{array}{l}\text { Benzo }[b] \text { fluoranthene } \\
5\end{array}$ & ND & ND & ND & ND & ND & ND & ND & ND & ND & $\mathrm{ND}$ & $\begin{array}{l}0.07 \pm \\
0.000 \\
\end{array}$ & ND & ND & ND & ND & $\begin{array}{c}0.00 \\
02\end{array}$ \\
\hline $\begin{array}{l}\text { Benzo }[k] \text { fluoranthene } \\
5\end{array}$ & ND & ND & ND & ND & ND & ND & ND & ND & ND & ND & ND & ND & ND & ND & $\begin{array}{l}0.01 \pm \\
0.000\end{array}$ & $\begin{array}{c}0.00 \\
02\end{array}$ \\
\hline $\begin{array}{c}\text { Benzo[e]pyrene } \\
5\end{array}$ & ND & ND & ND & ND & ND & ND & ND & ND & ND & $\begin{array}{c}0.01 \pm 0 . \\
000\end{array}$ & $\begin{array}{l}0.06 \pm \\
0.001 \\
\end{array}$ & ND & $\begin{array}{l}0.01 \pm \\
0.000\end{array}$ & ND & ND & $\begin{array}{c}0.00 \\
02\end{array}$ \\
\hline $\begin{array}{c}\text { Dibenzo }[a, h] \text { anthrace } \\
\text { ne } 5\end{array}$ & $\mathrm{ND}$ & $\mathrm{ND}$ & ND & ND & ND & ND & ND & $\mathrm{ND}$ & ND & ND & ND & ND & ND & ND & ND & $\begin{array}{c}0.00 \\
03\end{array}$ \\
\hline $\begin{array}{l}\text { Indeno[1,2,3- } \\
c d] \text { pyrene } 6\end{array}$ & ND & ND & ND & ND & ND & ND & ND & ND & ND & ND & ND & ND & ND & ND & ND & $\begin{array}{c}0.00 \\
04\end{array}$ \\
\hline $\begin{array}{c}\text { Benzo[ghi]perylene } \\
6\end{array}$ & ND & ND & ND & ND & ND & ND & ND & ND & ND & ND & ND & ND & ND & ND & ND & $\begin{array}{c}0.00 \\
02\end{array}$ \\
\hline No. of PAHs per site & 1 & 0 & 5 & 1 & 1 & 2 & 0 & 2 & 1 & 10 & 12 & 1 & 8 & 6 & 6 & \\
\hline $\begin{array}{c}\text { Total PAHs } \\
\text { Concentration/Site }\end{array}$ & 0.00 & 0.00 & 0.28 & 0.13 & 0.08 & 0.11 & 0.00 & $\begin{array}{c}0.1 \\
4\end{array}$ & 0.16 & 2.44 & 11.54 & 0.06 & 1.30 & 0.25 & 0.30 & $\begin{array}{l}\leq 0.2 \\
\mathrm{mg} / \\
\mathrm{m}^{3}\end{array}$ \\
\hline
\end{tabular}

$\mathrm{TLV}=$ Threshold limit value; $\mathrm{ND}=$ Not detected; $\mathrm{ACS}=$ Achusa village; $\mathrm{ANK}=$ Ankpa quarters; $\mathrm{APR}=\mathrm{Apir}$ village; CT5=Court 5; FLC=Federal Low Cost, North Bank; FMC $=$ Federal Medical Center, Wadata; GAD $=$ Gaadi; $\mathrm{IDE}=$ Idye village; $\mathrm{KSO}=$ Kanshio; WKM= Wurukum, MMK= Modern Market; MUR=Mu River; WBM=Water Board Makurdi; BSU= Benue State University; NBM = North Bank Market

Table 2: Molecular ratios of quantified PAHs in moss smaples

\begin{tabular}{|c|c|c|c|c|c|c|}
\hline & $\begin{array}{c}\text { WK } \\
\text { M }\end{array}$ & APR & MMK & WBM & BSU & NBM \\
\hline & & & & & & \\
\hline $\mathrm{FlA} /(\mathrm{FlA}+\mathrm{Py})$ & 0.40 & - & 0.75 & - & - & - \\
\hline $\mathrm{A} /(\mathrm{A}+\mathrm{Ph})$ & 0.15 & 0.40 & 0.46 & 0.14 & 0.75 & 0.64 \\
\hline $\begin{array}{c}\mathrm{BaA} /(\mathrm{BaA}+ \\
\mathrm{Chy})\end{array}$ & - & - & 0.58 & - & - & - \\
\hline $\mathrm{Ph} / \mathrm{A}$ & 5.50 & 1.50 & 1.18 & 6.00 & 0.33 & 0.57 \\
\hline
\end{tabular}

Table 3: Pearson correlation matrix of the molecular ratios used for source apportionment

\begin{tabular}{|c|c|c|c|c|}
\hline \multicolumn{5}{|c|}{ Correlations $^{\mathrm{c}}$} \\
\hline \multirow{2}{*}{$\mathrm{FIA} /(\mathrm{A}+\mathrm{Py})$} & $\begin{array}{c}\mathrm{FIA} /(\mathrm{A}+ \\
\text { Py) }\end{array}$ & $\mathrm{A} /(\mathrm{A}+\mathrm{Ph})$ & $\begin{array}{c}\text { BaA/(BaA } \\
+ \text { Chy })\end{array}$ & $\mathrm{Ph} / \mathrm{A}$ \\
\hline & 1 & & & \\
\hline \multirow{2}{*}{$\mathrm{A} /(\mathrm{A}+\mathrm{Ph})$} & -.168 & 1 & & \\
\cline { 2 - 5 } & .750 & & & \\
\hline \multirow{2}{*}{$\begin{array}{c}\mathrm{BaA} /(\mathrm{BaA}+ \\
\mathrm{Chy})\end{array}$} & $.863^{*}$ & .111 & 1 & \\
\hline & .027 & .834 & & \\
\hline $\mathrm{Ph} / \mathrm{A}$ & .048 & $-.927^{* *}$ & -.257 & 1 \\
\hline
\end{tabular}




\begin{tabular}{|c|c|c|c|c|}
\hline & .928 & .008 & .624 & \\
\hline \multicolumn{4}{|c|}{ *. Correlation is significant at the 0.05 level (2-tailed). } \\
**. Correlation is significant at the 0.01 level (2-tailed). \\
\hline \multicolumn{4}{|c|}{ c. Listwise $\mathrm{N}=6$} \\
\hline \multicolumn{4}{|c|}{ Descriptive Statistics } \\
\hline $\begin{array}{c}\text { FIA } /(\mathrm{FIA}+ \\
\mathrm{Py})\end{array}$ & Mean & Std. Deviation & $\mathrm{N}$ \\
\hline $\mathrm{A} /(\mathrm{A}+\mathrm{Ph})$ & .1917 & .31689 & 6 \\
\hline $\begin{array}{c}\mathrm{BaA} /(\mathrm{BaA} \\
+\mathrm{Chy})\end{array}$ & .4067 & .23475 & 6 \\
\hline $\mathrm{Ph} / \mathrm{A}$ & .0967 & .23678 & 6 \\
\hline
\end{tabular}

\section{RECOMMENDATIONS}

Other biological indicators could be employed in the investigation of atmospheric pollution of PAHs to authenticate data by moss plants, and other air sampling techniques. Secondly, uncontrolled burning of solid wastes and vegetation must be regulated to check PAHs load in the atmosphere.

\section{CONFLICT OF INTEREST}

The authors declare that there is no conflict of interest.

\section{REFERENCES}

[1] Abdel-Shafy, H. I. (2016). A review on polycyclic aromatic hydrocarbons: Source, environmental impact, effect on human health and remediation". Egyptian Journal of Petroleum. 25 (1): 107-123.

[2] Adeniyi, A. O., Okoh, O. O. and Okoh, A. I. (2019). Levels of Polycyclic Aromatic Hydrocarbons in the water and sediment of Buffalo River Estuary, South Africa and their Health Risk Assessment. Arh. Environ. Contam. Toxicol. 76(4): 657 - 669. https://doi.org/10.1007/s00244-19-00617-w

[3] Adie, P. A., Torsabo, S. T,Uno, U. O. and Ajegi, J. (2014). Funaria hygrometrica moss as Bio-indicator of atmospheric pollution of heavy metals in Makurdi and Environs, North Central Nigeria. Research Journal of Chemical Sciences. 4(10): 1-8

[4] Amel, H-C. (2014). Usefulness of bioindicators and biometers in pollution biomonitoring Sfax University Tunisia, International Journal of Biotechnology for wellness industries, 3, 19-26.

[5] Buck, W. R. and Bernard, G. (2000). "Morphology and classification of mosses", pages 71-123 in A. Jonathan Shaw \& Bernard Goffinet (Eds.), Bryophyte Biology. Cambridge: Cambridge University Press.

[6] Chen, Y., Zhu, L. and Zhou, R. (2007). Characterization and distribution of polycyclic aromatic hydrocarbon in surface water and sediments from Qiantang River, China. Journal of Hazardous Materials 141(1): 148 - 155 .

[7] Choi, H., Harrison, R., Komulainen, H., and Delgado S. J. (2010). "Polycyclic aromatic hydrocarbons". WHO Guidelines for Indoor Air Quality: Selected Pollutants. Geneva: World Health Organization.

[8] da Silva, T. F., Azevedo, D. and Neto, F. R. (2007). Distribution of polycyclic aromatic hydrocarbons in surface sediments and waters from Guanabara Bay, Rio de Janeiro, Brazil. Journal of Brazilian Chemical Society, 18(2): 628-637.

[9] Edokpayi, J. N., Odiyo, J. O.. Popoola, O. E. and Msagati, T. A. (2016). Determination and distribution of polycyclic aromatic htdrocarbons in rivers, sediments and wastewater effluents in Vhembe District, South Africa. Int. J. Environ. Res. Publ Health 13(387): $1-12$
[10] Ekpo, B. O., Oyo-Ita, O. E., Offem, J. O. and Adie, P. A. (2012). Anthropogenic PAHs in Sediment-Dwelling Biota from Mangrove areas of the Calabar River, SE Niger Delta, Nigeria. Environment and Natural Resources Research. 2(4): 89-100.

[11] EMEA (2006). Validation of Analytical Procedures: Text and Methodology. European Medicines Agency, EMEA, International Conference on Harmonization, ICH Topic Q2(R1)

[12] Goffinet, B. and Buck, W. R. (2004). Systematics of the Bryophyta (Mosses): From molecules to a revised classification. Monographs in Systematic Botany. Molecular Systematics of Bryophytes. 98. Missouri Botanical Garden Press. pp. 205-239.

[13] Guo, W., He, M., Yang, ZLin, C., Quan, X., and Wang, H. (2007). Distribution of polucyclic aromatic hydrocarbons in water, suspended particulate matter and sediment from Daliao River watershed, China. Chemosphere 68(1): 93 -104.

[14] Hong, W-J., Jia, H., Li, Y-F.,Sun, Y., Liu, X., and Wang, L. (2016). Polycyclic Aromatic Hydrocarbons (PAHs) and alkylated PAHs in the coastal seawater, surface sediments and oyster from Dalian, Northeast China. Ecotoxicol. Environ. Saf. 128: 11 - 20

[15] Kim, K.-H., Jahan, S. A. and Kabir, E. (2011). A review of diseases associated with household air pollution due to the use of biomass fuels. Journal of Hazardous Materials. 192 (2): 425-431.

[16] Lane, D. A. (1989). The fate of Polycyclic Aromatic Compounds in the atmosphere and during sampling. In: Chemical Analysis of Polycyclic Aromatic Compounds. T. V-Dinh (Ed), J. Wiley and Sons. Pp $31-58$.

[17] Li, B., Feng C, Li X, Chen Y, Niu J and Shen Z (2012) Spatial distribution and source apportionment of PAHs in surficial sediments of the Yangtze Estuary, China. Mar. Pollut. Bull. 64 (3), 636-643. https://doi.org/10.1016/j.marpolbul.2011.12.005

[18] Li, J., Shang, X., Zhao, Z., Tanguay, R. L., Dong, Q. and Huang C (2010) Polycyclic aromatic hydrocarbons in water, sediment, soil, and plants of the Aojiang River waterway in Wenzhou, China. $J$. Hazardous Mater. 173 (1-3) 75-81. https://doi.org/10.1016/j. jhazmat.2009.08.050

[19] Lim, T. B, Xu, R, Tan, B. \& Obbard, J.P. (2006). Persistent ortganic pollutants in moss as bioindicators of atmospheric pollution in Singapore. Elsevier, 64, 596-602.

[20] Liu, M., Feng, J., Hu, P., Tan, L., Zhang, X. and Sun, J. (2016). Spatial temporal distributions, sources of polycyclic aromatic hydrocarbons (PAHs) in surface water and suspended particular matter from the upper reach of Huaihe River, China. Ecol. Eng. 95 143-151. https://doi.org/10.1016/j.ecoleng.2016.06.045

[21] Liu, Y., Shen, J., Chen, Z., Ren, N. and Li, Y. (2013). Distribution of polycyclic aromatic hydrocarbons in surface water and sediment near a drinking water reservoir in Northeastern China. Environ. Sci. Pollut. Res. 20 2535-2545. https://doi.org/10.1007/s11356-012-1164-x

[22] Liu, S., Liu, X. Liu, M., Yang, B., Cheng, L., Li, Y. and Qadeer, A. (2016). Levels, sources and risk assessment of PAHs in multiphases from urbanized river network system in Shangai. Environmental Pollution, 219: 555 - 567.

[23] Ma, W-L., Liu, L-Y., Qi, H., Zhang, Z-F., Song, W-W., Shen, JM., Chen, Z-L., Ren, N-Q, Grabuski J and Li, Y-F (2013) Polycyclic aromatic hydrocarbons in water, sediment and soil of the Songhua RiverBasin, China. Environ. Moni. Assess. 1858399 8409. https://doi.

[24] Offiong, B., Orok, E. Oyo-Ita, E., Oros, D. R., Simoneit, B. R. T. (2012). Distribution and sources of polycyclic aromatic hydrocarbons in surface sediments from the Cross River Estuary, S. E. Niger Delta, Nigeria. Environmental Monitoring Assessment, 184: $1037-1047$

[25] Oyo-Ita, O. E. Offem, J. O. Ekpo, B. O. and Adie, P. A. (2013). Anthropogenic PAHs in mangrove sediments of the Calabar River, SE Niger Delta, Nigeria. Applied Geochemistry, 28: $212-219$.

[26] Ramesh, A.; Archibong, A.; Hood, D. B.; Guo, Z.; Loganathan, B. G. (2011). Global environmental distribution and human health effects of polycyclic aromatic hydrocarbons. Global Contamination Trends of Persistent Organic Chemicals. Boca Raton, FL: CRC Press. pp. 97-126. 
[27] Ravindra, K.; Sokhi, R.; Van Grieken, R. (2008). "Atmospheric polycyclic aromatic hydrocarbons: Source attribution, emission factors and regulation". Atmospheric Environment. 42 (13): 28952921.

[28] Santos, E., Souza, M. R. R., Vilela, A. R., Soares, L. S., Frena, M. and Alexandre, M. R. (2018). Polycyclic Aromatic Hydrocarbons (PAHs) in superficial water from a tropical estuarine system: distribution, seasonal variations, sources and ecological risk assessment. Marine Pollution Bulletin 127: 352 - 358

[29] Sowles, J. (2005). Maine Environmental Priorities project issues: Toxic contamination of coastal waters. http://maine.gov

[30] Srogi, K. (2007). Monitoring of environmental exposure to polycyclic aromatic hydrocarbons: a review. Environmental Chemistry Letters. 5 (4): 169-195.

[31] Tavakoly Sany, S. B., Hasim, R. Salleh A., Rezayi, M. and Mehdinia, A. (2014). Polycyclic Aromatic Hydrocarbons in Coastal Sediments of Klang Strait, Malaysia: Distribution Pattern, Risk Assessment and Sources. PLoS ONE 9(4): e94907. doi: 10.1371/journal.pone.0094907

[32] US-EPA (2010). United State Environmental Protection Agency, Method 610, Polynuclear Aromatic Hydrocarbons.
[33] Wang, Z., Ma, X., Na, G., Lin, Z., Ding, Q., and Yao, Z. (2009) Correlations between physicochemical properties of PAHs and their distribution in soil, moss and reindeer dung at NyĹlesund of the Arctic. Environ Pollut. 157: 3132-3136. DOI:10.1016/j.envpol.2009.05.01

[34] Xu, J., Guo, J-Y., Liu, G-R., Shi, G-L., Guo, C-S., Zhang, Y and Fend, Y-C. (2014). Historical Trends of Concentrations, Source contributions and toxicities for PAHs in dated sediments cores from five lakes Western China. Science of the Total Environment, $470-471: \quad 519 \quad-\quad 526$. http://dx.doi.org/10.1016/j.scitotenv.2013.10.022

[35] Yan, B., Abrajano, T. A., Bopp, R. F., Benedict, L. A., Chaky, D. A., Perry, E., Song, J. and Keane, D. P. (2006). Combined application of $\delta^{13} \mathrm{C}$ and molecular ratios in sediment core for PAHs source apportionment in the New York/New Jersey Harbor complex. Organic Geochemistry, 37: 674 - 687

[36] Yunker, M. B., Macdonald, R. W.,Brewer, R., Mitchell, R. H., Goyette, D. and Sylvestre, S. (2002). PAHs in the Fraser River Basin: a critical appraisal of PAHs source and composting. Organic Geochemistry, 33(4): 489 - 515 